\title{
The structural advancement of religious communities and the commercialisation of the Christian religion in Nigeria
}

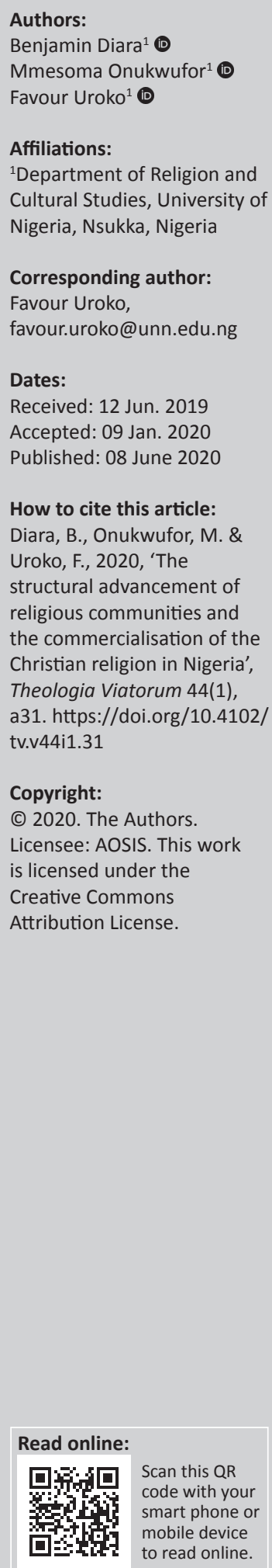

\begin{abstract}
This article examines the activities of Christian religious communities and the birth of a commercialised Christian religion. It begins by creating an atmosphere that the Nigerians find themselves in, and explaining as to why they rely more on religious vendors for solutions to their physical and spiritual problems. Thus, the real causalities are the people with no contentment. The commercialisation of religion in Nigeria has been characterised by increased poverty and social vices such as armed robbery, bad leadership and bad citizenship. Findings reveal that adherents of the various churches that have commercialised their blessings comprise both the poor and the rich of the society. The poor are seeking God for instant blessing, while the rich are seeking God for the sustainability of their wealth and protection. True religion is now lost in Nigeria. Some pastors treat the church as an investment, expecting to get something in return personally when the institution prospers financially. This is evident in the rise in sugar-coated preaching in most Nigerian churches. It was discovered that commercialisation of churches is mainly for financial gains, and it is an offshoot of the proliferation of churches in Nigeria.
\end{abstract}

Keywords: commercialised religion; Christianity; proliferation of churches in Nigeria; true religion; prosperity preaching.

\section{Introduction}

In 2010, while I was running a programme at the University of Nigeria, Nsukka, I discovered that almost every lecture theatre had been taken over by one church or the other. This then triggered my interest in carrying out research on religious mechanise and profiteering in Nigeria.

Christianity is the religion of Christ, no doubt. Its doctrines are hinged on the conversion of votaries of other religions to Christianity. In fact, Christ instructed Christians to preach the gospel. This is what is called evangelism. Evangelism is the commitment to or act of publicly preaching the gospel with the intention to spread the message and teachings of Jesus Christ (Bible Study Tools 2018). The preaching of the gospel goes with the planting of churches. The churches are there to take care of the teeming population of converted souls. In Nigeria, the great commission has taken a new dimension. There is hardly any street in Nigeria where a church would not be found. Furthermore, there is hardly any compound where you will not find one denominational fellowship or the other. It is good to note that these various churches are noted for their teachings on miracles and prosperity. One would not blame the essence of these teachings. This is because of the current issue of many ailments in Nigeria. Rowan noted that life-threatening illness brings Nigerians face to face with the supernatural (Rowan 2013). Other driving factors are poverty, spiritual oppression, witchcraft, witch-hunting and physical oppression in Nigeria. A feature of the teachings of these churches is that financial prosperity is a sign of God's favour (Tomi 2011), and God's favour delivers one from these life problems. These teachings not only address the concern of salvation from sin but also emphasise that God will make everyone materially rich. Some pastors treat the religious institution as an investment, expecting to get something in return personally when the institution prospers financially (Mdakane 2017).

Unfortunately, this situation has shaped the theologies of churches and their missiology in Nigeria. Most of the churches have now started using their churches for amassing wealth and duping unsuspecting members. They emphasise the spiritual value of earthly or material blessings (Niemandt 2017:206). Many graduates who have failed to gain employment have resorted to opening churches all over, performing customised miracles and engaging in spiritual diabolic 
activities. The bitter truth is that the poor are at the receiving end of this malaise. Furthermore, native doctors have started opening churches in so many parts of Nigeria, especially in the east and west of Nigeria. Thus, Christianity is being used as a tool towards amassing money, fame and cheap popularity. In fact, it can be said that economic, spiritual and political prosperity are the motivating factors as to why churches strive in membership in Nigeria (Magbadelo 2014).

The aim of this article was to assess the effects of this commercialisation of religion on the Nigerian society, the Nigerian people and the Nigerian image. To arrive at the findings, the study utilised the phenomenological methodology. This is because previous studies have viewed this phenomenon from the historical lens. Data were collected through oral interviews, journals, textbooks, newspapers and other periodicals, and were descriptively analysed.

\section{Statement of the problem}

Most studies have focussed on the proliferation of churches in Nigeria (Adamolekun 2012; Adesanya 2011; Diara \& Onah 2014). Some of the articles projected that the proliferation of churches has increased laziness and unemployment in Nigeria. For these researchers, in this material world, prosperity preachers are perceived to encourage laziness among Christians who tend to believe that when they sow and are asked to receive in faith, a miracle of a sort would lay prosperity on their laps without having to work (Chioma 2017). Other scholars, who have engaged in the commercialisation of religion, fail to emphasise the place of Christianity in the commercialisation of religion in Nigeria. It is because of this lacuna that this research will focus on Christianity as the object of religion commercialisation in Nigeria.

\section{Christian church in Nigeria}

Church growth is the enlargement, expansion, advancement and spread of the influence of our Lord Jesus Christ through the spiritual and physical activities of the organic structure, hierarchical structure or sectarian structure of the Church. Towns (1986:63) saw the term 'church growth' to be associated with evangelism and/or missionary enterprises that imply outreach to the lost and their incorporation into a church, hence causing local church growth. According to Wagner (1971:12), church growth is 'all that is involved in bringing men and women who do not have a personal relationship with Jesus Christ into fellowship with Him and into responsible church membership'. Discussing the characteristics of church growth, Worancha (2012) advanced a question: what are the qualities of a growing church? He avers that a growing church should possess at least the following qualities (Worancha 2012):

(1) There must be a climate of happiness and loving God and one another in the church; (2) the church must have a Bible-centred atmosphere that demonstrates by its regular and continuous Bible studies; (3) the members of the church must be enthusiastic and become the cause for maintaining enthusiasm; (4) the church must be evangelistic and zealous to win lost souls for Christ; (5) a growing church should be able to claim backslidden members; (6) a growing church should have great faith to practice its vision; (7) a growing church should be a praying church that prays for its spiritual growth and for God's work throughout the world; and (8) a growing church believes in the Holy Scripture - 'Scripture and Scripture alone' - and do and live what it says (Mt 7:21; Lk 6:46; 11:28; Rm 2:13; 1 Jn 3:7; Ja 1:22). (p. 27)

From the above, one can discover that real church growth is measured by the internal (spiritual) advancement of members than by the external (numerical) strength of members.

Church growth in Nigeria has taken various patterns right from its inception. Adamolekun (2012) in his work 'main trends in the church growth in Nigeria' discussed the periods of church growth in Nigeria. He traced church growth from the period of the introduction of Latin Christianity, the period of denominationalism and missionary activities, evolution of independent churches, indigenous African churches and then the period of Charismatic, Evangelical and Pentecostal churches. Among all these periods of church growth in Nigeria, it was the Charismatic and Evangelical movements that ushered in the proliferation of churches and the establishment of churches for commercial purposes.

\section{Commercialisation of religion from the testaments}

Commercialisation of the Christian religion seems to have gotten prominence during the time of Jesus Christ and also after his death. From the scriptures, one can carefully trace pieces of evidence of commercialisation of religion. Nwanganga (2017) noted that prophets, such as Amos, Micah and Ezekiel, decried the use of religion for business or economic gains. The major sins as were noted in these scriptural passages include perversion of worship practises, empty religious formalism (Mi 6:6-7), oppression of the poor and the defenceless (Am 2:2, 8-9), perversion of justice through bribery and dishonest business practises, idolatry and violence. Religious leaders were also accused of commercialisation of religion by serving people for economic gain. Prophet Ezekiel was also against the false prophets who commercialised religion (Ezk 13:1-23). John (as cited in Nwanganga 2017:3) noted that the prophets were concerned with their own welfare, rather than the nations' welfare. Materialism was their master'.

In the New Testament, there also appeared clear instances of commercialisation of religion in Jesus' time, which he seriously frowned at. This was illustrated in Matthew 21:12-13, Mark 11:15-18 and Luke 19:45-46, where Jesus clearly expressed his anger against those people who turned the house of God into a den of robbers by money changers and those involved in the sale of doves in the temple. He rebuked the religious leaders for desecration of the temple. A man like Simeon, the sorcerer, also attempted to purchase the anointing with his money (Ac 8:4-24) and apostle Paul in the same vein talked about minsters of God whose God is their selfish interest (Phlp 3:18-19). These scenarios depict commercialisation of the Christian religion as a violation of religious ethics. 


\section{The problem with Nigeria}

Nigeria, no doubt, is a country blessed with abundant human and natural resources. However, because of inefficient or lack of servant leadership, the nation has continued to wallow in poverty, abject poverty and extreme poverty situations. Poverty can be define as a severe lack of physical and mental well-being, closely associated with inadequate economic resources and consumption (Baratz \& Grigsby 1971:120). The poverty level has gone so high that in the year 2018, Nigeria was pronounced as the poverty capital of the world.

More than a few Nigerians are homeless. Many of them sleep under bridges and in front of people stores and shops. This is because they cannot afford housing and other essential amenities. Most poor people in Nigeria do not have access to housing (Dauda 2016). Furthermore, revelations were made by the Federal Mortgage Bank of Nigeria that more than 9 million Nigerians lack access to affordable housing (Egobiambu 2019).

Also, a high percentage of Nigerians cannot feed themselves twice a day. This is why there is a high level of malnutrition and epidemics in most places in Nigeria. Most families have allowed their children to beg on the streets to take care of themselves. Nigeria has continued to remain in this sad state because the country is unable to feed its citizens (Vanguard 2016).

In addition, there are high unemployment indices. Skilled, unskilled and semi-skilled graduates, and non-graduates, are not able to find a job. Even those with entrepreneurial skills and abilities cannot be assisted with start up capital or other assistance. Aiyedogbon and Ohwofasa (2012) reported that unemployment is a barrier to social progress, and to prevent its undesirable consequence on poverty, unemployment figures prominently in the development objectives of Nigeria. It is ironical that the youths who muster the courage to engage in one business or the other are on a daily basis harassed by the Government of Nigeria with high lighting and rental charges. Majority of the Nigerians find it difficult to separate physical issues from spiritual issues, and hence they leave every issue in life to the control of spiritual forces, even when it is very obvious that such problems could be of a physical nature or even self-induced (Rapmoney 2016).

It is very important to note that most Nigerians believe that only God can help them survive. This religious idea of the African people has always taken its orientation from their ancestors, in which the ancestors kindle and direct the affairs of the people; thus, it can be argued that the historical religion of the African people has helped shape their perception about God (Gbote \& Kgatla 2014). Most of them also believe that their poor or sad situation is caused by the witches and wizards in their villages. Thus, they seek spiritual help to salvage themselves from this sorry state of affairs. Most religious persons look at the psychological state of these Nigerians. Thus, the priest uses the name of God to extort from those seeking spiritual help to the problems. This is the reason for the shameful proliferation of churches in every nook and cranny of Nigeria.

\section{The commercialisation of the Christian religion as the opium of Nigerians}

Just to leverage on Karl Marx's thesis, Christianity is now the opium of Nigerians. As most Nigerians go to churches seeking spiritual help to escape from the clutches of poverty and sickness, God-called and self-called pastors are now maximising on the faith of these unsuspecting Christian adherents and indirectly stealing from them. For a better understanding, commercialisation of religion 'centres on a complex liaison of speech acts surrounding faith, wealth, health and victory, combined with ritual practices around secondary evidences of divine blessings' (Heuser 2016:1).

The term commercialisation denotes the process of running something principally for financial gain. Nwadialor and Umeanolue (2013) described commercialisation as a process or cycle of introducing a new product or production matter into the market. Ahmad and Eijaz (2011:186) saw it as a relative term that can be defined in many ways, such as 'an integral part of the capitalist society to increase the profit through cosmetic and gaudy advertisement/marketing in the process of introducing or launching any product'. They further explain commercialisation of religion as being of two types - for the awareness of the people for practising religion and for the exploitation and monopolisation of economic resources.

While Ahmad and Eijaz saw one side of commercialisation of religion, namely, creating awareness to people to practise religion, Nwanganga (2017) saw the two sides as simply schemes for economic gain. He explains church commercialisation in two lights: firstly, the application of commercial principles in the running of the church or applying business principles to church administration, running it as a business for economic gain; secondly, the manipulation of the church or Christianity and its services (spiritual and emotional), with implied intentions to exploit members or prospects for economic or financial gain. He also describes it as conducting the core mandate of the church, namely, soul winning and attending to the spiritual and emotional needs of members with the sole aim of benefiting financially. For the purpose of this research, the researchers wish to define commercialisation of religion as any action carried out by religious clerics that is directed towards the exploitation of members with prospects for economic or financial gain.

In the present-day Nigeria, many churches have become instruments of exploitation and manipulation of people for economic gain. The root cause of the commercialisation of the gospel in Nigeria can be seen as what Kalu (2008) described as the market theory. He linked commercialisation of the gospel to the market theory built around the idea that sees 
the religious space as being similar to the marketplace. He examined the commercialisation of religion as a commodity because messages are packaged as products in a competitive marketplace. Using marketing strategies, religious leaders find it very easy to dupe gullible consumers and adherents presenting their own 'religious product' as the best. Commercialisation of the gospel in Nigeria is played out in so many ways. These various ways include but are not limited to manipulation of the gospel message, divinations, selling of religious 'products', healings and miracles, subtle threat, etc. (Essien 2010).

Prosperity preachers do this through false prophesying. This is seen among ministers who are not well paid by their employers. Some of them are poorly paid, so they use various gimmicks to earn more money. Nwadialor (2015) also advanced a list of various reasons why churches are commercialised. Some of these reasons include influence of secular politics, influence of modernity, economic hardship, influence of African cosmology and the influence of mass media.

They do this through tithing. Another strategy used by prosperity preachers is mounting of big programmes, such as citywide crusades, where prophecies are released and special offerings are collected. To entice people to attend these programmes, bogus titles are used as themes for their supposed messages. Big posters are used to advertise and publicise their programmes. Those who do not have enough funds to organise big programmes resort to preaching on the streets and buses, and demanding offerings to support God's work. People are deceived into buying wrist bands, stickers, holy water, miracle oil, miracle candle, magical handkerchiefs, blessed pen and pencils (Olawole 2005). Miracles or healings have become the 'real thing' today.

These priests do this through seed sowing. The manipulation of the gospel is played out in several ways by these businessminded gospel preachers. People are made to believe that what brings them prosperity is not their hard work but the level of the seeds sown (Olawole 2005). While some of these preachers assure the members that these seeds are for the expansion of God's kingdom and for evangelism, they end up using them to enrich their pockets. The truth is also being twisted to suit the ears of the people so that they can be willing to bring out their money just as was found during the days of the prophets in the Old Testament. The congregation is also deceived by way of divination where the so-called prophets make predictions for the future and make attempts to uncover the past.

It is very important to note that the increase in the commercialisation of religion, especially of Christianity, is caused by the unemployment among the youth. Unemployment is also a major contributing factor to the commercialisation of churches in Nigeria. Nwangana (2017) underscored the fact that after a long search for gainful employment, many frustrated people resorted to pastoral work without genuinely being called by God. Some of them who possess oratory and communication skills open ministries, which later metamorphosed into full churches. This situation has led to the proliferation of churches, which apparently fan the embers of church commercialisation. On this, Diara (2011:66) wrote that Pentecostalism is now one of the most lucrative businesses in the country, and diviners and native doctors disguise themselves in cloaks and garments akin to those of the prophets and priests to deceive the poor and helpless masses who are desperate for one miracle or the other. These people are those who, on the basis of their faith, have resolved not to consult the diviners or native doctors for solutions to their problems. In this way, many people consult occultic and diabolic personnel today in the name of 'men of God' without knowing.

\section{The impacts of a commercialised Christian religion on the Nigerians}

The influence of the commercialisation of Christianity in Nigeria cannot be understated. Its impacts revolve around the following points:

- Political consequences: This is a reason for the bad political leadership in Nigeria. During elections, unscrupulous leaders give millions of naira to the pastor or the priest. The pastor or the priest, in turn, prays and blesses the candidate. This has encouraged political office holders to misbehave, as according to them, God is only interested in their tithes and offerings.

- Educational consequences: This has led so many promising graduates to opt for ministry instead of practising what they learnt. Many of them make fake prophecies and extort their victims in the name of the Christian God. Furthermore, some students have donated their laptops, school fees and property to the churches in the name of sowing seeds. These so-called men of God also craftily employ occultic means to manipulate people into ignorantly donating their cars, landed properties and money to them. It is funny to observe that even some actors and actresses have suddenly become prophetesses and pastors because they have realised that the church business seems to be even more lucrative than the entertainment industry. Ejiogu (2000:7) observed rightly, 'the churches may surely be increasing by leaps and bounds, parading millions of "born again", a disruptive moral crisis has regrettably over taken our modern Nigerian society'.

- Social consequences: This is the reason for the high level of prostitution, armed robbery, rape, kidnapping and rituals in the society. Many of these prostitutes, who should have been corrected by their pastors, instead are prayed for and encouraged to go with God's blessing in whatever they do. In the church today, as in the secular world, human needs and acceptance define the gospel message. As a result of commercialisation, some churches today build their teachings on emotions, reason and philosophies at the expense of the biblical truth. People are no longer taught Kingdom Principles as Jesus taught his disciples. The modern-day preaching and teaching is 
based on the trend of events in the society. Sadly, strange people with strange doctrines have invaded the church. Ejizu (2008:19-21) underscored the phenomenon that the more the proliferation of churches in Nigeria, the more the decline of the faith experience in spiritual commitment, morality and practical Christian living. Many of the churches today are significantly occupied with mundane affairs of this world, as shaped by the Nigerian social system, which has facilitated rapid secularisation of Christian spirituality.

- Religious consequences: This is the reason for the lack of trust in anything related to God among some distraught Nigerians. They see every church and preaching centre as a profit-making entity. Furthermore, the higher the level of religious commitment among Nigerians, the higher the level of social evils in the Nigerian society. This is the reason why many Nigerians have lost faith in the Christianity.

- Economic consequence: The youths are not prepared to work. They want free and quick money. Christianity as presented by these commercialised preachers brings quick money. Thus, the youths are prepared to give whatsoever they have to bribe God into giving them heaven on earth. In fact, it would not be a surprise if an unemployed Nigerian believes that God would give a Prado jeep the next day.

\section{Recommendations}

To reduce the growing commercialisation ethics of minsters and owners of thousands of churches in Nigeria, the following recommendations can be put into practice:

- The citizens are the tools that have been sustaining the commercialisation of the Christian religion. People should know the difference between things that need a spiritual touch and those that need a physical touch. They should learn from the stories of others, rather than learn as victims.

- All churches in Nigeria should be registered. This will ensure a level of control over these religious communities.

- All Christian religious practitioners in Nigeria should be registered.

- Seminars and conferences should be held for ministers of God where they would be taught social ethics and moral ethics in mission work.

- The Christian Association of Nigeria should partner with the Federal Government of Nigeria to chalk out strategies on how to discourage the proliferation of churches and the commercialisation of their activities.

\section{Conclusion}

Church commercialisation is simply a deviation from the ethical code of the institution of the church. The church was instituted to propagate the gospel of Jesus Christ, but the discussed deviation results in deceitful practices or twisting of the scriptures for economic gains, and the church is faced with the problems of fraud, rivalry, perversion of the truth and syncretism. The implication here is that church commercialisation runs counter to the church's tenets of sacredness, purity, holiness and Jesus' admonition of 'freely you have received, freely you must give'. Finally, church commercialisation is an aberration and is doing more harm than good to the growth of the church in Nigeria and should be stopped by all means. War against corruption should be carried into religious groups and churches so as to restore the image of the church and the God it represents.

\section{Acknowledgements}

We sincerely appreciate the efforts of the Theologia Viatorum journal team in getting this article published. God bless you all.

\section{Competing interests}

The authors have declared that no competing interests exist.

\section{Authors' contributions}

All authors contributed equally to this work.

\section{Ethical consideration}

This article followed all ethical standards for research without direct contact with human or animal subjects.

\section{Funding information}

This research received no specific grant from any funding agency in the public, commercial or not-for-profit sectors.

\section{Data availability statement}

Data sharing is not applicable to this article as no new data were created or analysed in this study.

\section{Disclaimer}

The views and opinions expressed in this article are those of the authors and do not necessarily reflect the official policy or position of any affliliated agency of the authors.

\section{References}

Adamolekun, T., 2012, 'Main trends in the church growth in Nigeria', European Scientific Journal 8(23), 1-12.

Adesanya, 1.O., 2011, 'Environmental effects of church proliferation: The Redeemed Christian church of God as a case study', International Journal of Humanities and Social Science 1(15), 177-182.

Ahmad, R.E. \& Eijaz, A., 2011, 'Commercialization of religion in Pakistan', American International Journal of Contemporary Research 1(2), 186.

Ayegboyin, D. \& Ishola, A., 1997, African indigenous churches: An historical perspective, Greater Heights Publications, Lagos.

Baratz, M.S. \& Grigsby, W.G., 1971, 'Thoughts on Poverty and Its Elimination', Journal of Social Policy 1(2), 119-134.

Bible Study Tools, 2018, Bible verses about evangelism, viewed 12 February 2018, from https://www.biblestudytools.com/topical-verses/bible-verses-aboutevangelism/

Chioma, G., 2017, 'Disturbing change in Christianity', VanguardNews, 1.

Dauda, R.S., 2016, 'Poverty and economic growth in Nigeria: Issues and policies', Journal of Poverty 21(1), 61-79. https://doi.org/10.1080/10875549.2016.1141383 
Diara, B.C., 2011, 'Climate change: An eschatological sign of the second coming of Christ', Journal of Bible Exposition: Nsukka Bible Research Institute 1(1), 1.

Diara, B.C.D. \& Onah, N.K., 2004, 'The phenomenal growth of Pentecostalism in the contemporary Nigerian society: A challenge to mainline churches', Mediterranean Journal of Social Sciences 5(6), 395.

Egobiambu, E., 2019, Nine million Nigerians without access to affordable housing FMBN, viewed 12 July 2019, from https://www.concisenews.global/2019/07/12/ nine-million-nigerians-without-access-to-affordable-housing-fmbn/

Ejiogu, A., 2000, Morality and national development: A case for national rebirth, Superlative Services Ltd, Lagos.

Ejizu, C.I., 2008, Between religion and morality: Their inter-connection and significance in public life, Inaugural Lecture Series No. 59, University of Port Harcourt, Port Harcourt.

Essien, A.M., 2010, 'Proliferation of churches: A leeway to commercialization of religion', European Journal of Scientific Research 45(4), 649-657.

Ferraro, V., 2003, 'Globalizing weakness: Is global poverty a threat to the interest of states?', Environmental Change and Security Project 9, 12-19.

Gbote, E.Z.M. \& Kgatla, S.T., 2014, 'Prosperity gospel: A missiological assessment', HTS Teologiese Studies/ Theological Studies 70(1), \#2105. https://doi.org/10.4102/ hts.v70i1.2105

Heuser, A., 2016, 'Charting African prosperity gospel economies', HTS Teologiese Studies/Theological Studies 72(1), a3823. https://doi.org/10.4102/hts.v72i4.3823

Kalu, O.U., 2008, African Pentecostalism: An introduction, Oxford University, Oxford. https://doi.org/10.1093/acprof:oso/9780195340006.001.0001

Magbadelo, J.O., 2004, 'Pentecostalism in Nigeria: Exploiting or edifying the masses?', African Sociological Review/Revue Africaine de Sociologie 8(2), 15-29. https://doi. org/10.4314/asr.v8i2.23248

Mdakane, M., 2017, 'Commercialisation of religion and abuse of people's belief systems: CRL Rights Commission briefing, viewed 27 June 2017, from https://pmg. org.za/committee-meeting/24693/
Niemandt, C.J.P., 2017, 'The prosperity gospel, the decolonisation of theology, and the abduction of missionary imagination', Missionalia 45(3), 203-219. https://doi. org/10.7832/45-3-199

Nwadialor, A.L., 2015, 'Pentecostal hermeneutics and the commercialization of the gospel message in Nigeria', International Journal of Research 2(2), 1.

Nwadialor, K.L. \& Umeanolue, I.L., 2013, 'Materialistic gospel message in contemporary Nigerian churches: A critique', Journal of Religion and Human Relations 1(5), 29-44.

Nwanganga, P.A., 2017, 'Church commercialization in Nigeria: Implications for public relations practice', Journal of Philosophy, Culture and Religion 28, 4, viewed 22 May 2018, from www.iiste.org

Olawole, A., 2005, A critique of the Pseudo-Nigerian bourgeoisie, viewed 11 June 2019, from https://www.dawodu.com/olawole2.htm

Rapmoney, 2016, Why do most Nigerians believe every problem is spiritual?, viewed 25 July 2016, from https://www.nairaland.com/3248309/why-most-nigeriansbelieve-every

Rowan, M.G., 2013, In Nigeria, miracles compete with modern medicine, viewed 19 December 2013, from https://www.theatlantic.com/international/archive/2013/ 12/in-nigeria-miracles-compete-with-modern-medicine/282517/

Tomi, O., 2011, Nigeria: Where religion is big business, viewed 22 August 2011, from https://www.bbc.com/news/world-africa-14573660

Towns, E.L., 1986, 'The relationship of church growth and systematic theology', Journal of the Evangelical Society 29(1), 63-70.

Vanguard, 2016, No nation can be considered great if that country cannot feed its citizens - Onu, viewed 01 August 2016, from https://www.vanguardngr. com/2016/08/onu-reassures-nigerians-food-sufficiency-years-time/

Wagner, C.P., 1971, Strategies for church growth: Tools for effective mission and evangelism, Regal Books, Ventura, CA.

Worancha, G., 2012, 'Factors affecting church growth in East Central Africa region: The Adventist concern', Asia-Africa Journal of Mission \& Ministry 5(19), 20-40. 